\title{
ANALISIS KESALAHAN PESERTA DIDIK PADA MATERI PERSAMAAN DAN PERTIDAKSAMAAN NILAI MUTLAK LINEAR SATU VARIABEL DI KELAS X SMA NEGERI 1 BANGKINANG KOTA
}

\author{
Zulfah \\ Universitas Pahlawan Tuanku Tambusai, Jl. Tuanku Tambusai No.23, Bangkinang \\ zulfahasni670@gmail.com
}

Submitted: 17-05-2017, Reviewed: 03-06-2017, Accepted: 04-09-2017

\begin{abstract}
This study aimed to describe aspects of the mistakes made by the students of class $X$ SMA Negeri 1 Bangkinang City in solving problems related to materials Equations and Inequalities Value Absolute Linear Single Variable, describing the most common mistake made students of class X SMA Negeri 1 Bangkinang City in solving problems related material Absolute Value Equations and Inequalities Linear Single variable, and to know how big the error percentage of students in each aspect of error. Method in this research is descriptive qualitative and quantitative desriptif. Qualitative description that describes the mistakes made kesalaha-learners by using words. While quantitative descriptive is describing big mistakes do learners using numbers. Suharsimi Arikunto (2006: 12) argues that research is a quantitative research approaches are required to use a lot of numbers, ranging from data collection, interpretation of these data, and displays the results. According Sumanto (1995: 77) descriptive study tried to describe and interpret what is there (could about the condition or relationship, a growing opinion, the ongoing process, due to actual or emerging inclinations). Based on the results of diagnostic tests on the material equations and linear inequalities absolute value of the variable obtained that there are students who make mistakes in solving problems related to the material. Mistakes made by learners consists of $71 \%$ false beliefs and misconceptions $69 \%$.
\end{abstract}

\section{Keywords: Error Analysis, The absolute value equations and inequalities}

\begin{abstract}
Abstrak. Penelitian ini bertujuan untuk mendeskripsikan aspek kesalahan yang dilakukan peserta didik kelas X SMA Negeri 1 Bangkinang Kota dalam menyelesaikan soal-soal terkait materi Persamaan dan Pertidaksamaan Nilai Mutlak Linear Satu Variabel, mendeskripsikan kesalahan yang paling banyak dilakukan peserta didik kelas X SMA Negeri 1 Bangkinang Kota dalam menyelesaikan soal-soal terkait materi Persamaan dan Pertidaksamaan Nilai Mutlak Linear Satu Variabel, serta mengetahui seberapa besar persentase kesalahan peserta didik pada masing-masing aspek kesalahan. Metode pada penelitian ini adalah metode deskriptif kualitatif dan desriptif kuantitatif. Deskriptif kualitatif yaitu menggambarkan kesalaha-kesalahan yang dilakukan peserta didik dengan menggunakan kata-kata. Sedangkan deskriptif kuantitatif yaitu menggambarkan besar kesalahan-kesalahan yang dilakukan peserta didik dengan menggunakan angka. Suharsimi Arikunto (2006: 12) mengemukakan bahwa penelitian kuantitatif adalah pendekatan penelitian yang banyak dituntut menggunakan angka, mulai dari pengumpulan data, penafsiran terhadap data tersebut, serta menampilkan hasil. Menurut Sumanto (1995: 77) penelitian deskriptif berusaha mendeskripsi dan menginterpretasi apa yang ada (bisa mengenai kondisi atau hubungan yang ada, pendapat yang sedang tumbuh, proses yang sedang berlangsung, akibat yang terjadi atau kecederungan yang tengah berkembang). Berdasarkan hasil tes diagnostik pada materi persamaan dan pertidaksamaan nilai mutlak linear satu variabel diperoleh bahwa masih terdapat peserta didik yang melakukan kesalahan dalam menyelesaikan soal terkait materi tersebut. Kesalahan yang dilakukan peserta didik terdiri dari kesalahan prinsip $71 \%$ dan kesalahan konsep 69\%.
\end{abstract}

Kata kunci: Analisis kesalahan, persamaan dan pertidaksamaan nilai mutlak 


\section{PENDAHULUAN}

Penguasaan matematika memberikan kemudahan kepada seluruh manusia dengan kegunaan yang beragam, mulai dari kemudahan dalam melakukan penjumlahan suatu benda, pemberian potongan harga suatu produk, penghitungan luas suatu bidang, hingga mendiagnosa cancer melalui aplikasi metode kernel perception berdasar unsur kimia darah. Kegunaan matematika pada setiap aspek seharusnya menyadarkan kita bahwa penguasaan matematika harus dimiliki oleh setiap manusia tanpa terkecuali. Hal ini diperkuat dengan yang disampaikan oleh Depdiknas (2004: 20) bahwa untuk dapat menguasai dan mencipta teknologi serta bertahan di masa depan diperlukan penguasaan matematika yang kuat sejak dini.

Seluruh manusia perlu dan harus memiliki penguasaan matematika pada tingkatan tertentu. Salah satu cara memperkenalkan matematika pada setiap manusia adalah melalui pembelajaran matematika di sekolah. Matematika merupakan salah satu mata pelajaran wajib mulai dari jenjang pendidikan dasar hingga sekolah menengah. Indonesia menjadikan matematika sebagai salah satu mata pelajaran yang masuk ke dalam mata pelajaran yang di ujian nasionalkan. Pada tingkat sekolah dasar peserta didik diharapkan sudah menguasai matematika dengan tujuan agar dapat menggunakannya pada kehidupan sehari-hari. Pada tingkat sekolah menengah, penguasaan matematika diharapkan membuat peserta didik dapat memperoleh manfaat seperti menjadi manusia yang lebih teliti, cermat, dan tidak ceroboh dalam bertindak. Melalui penguasaan matematika dan mempelajari matematika di sekolah peserta didik mengetahui bahwa banyak penerapan matematika dalam kehidupan nyata, bahkan hampir semua ilmu di dunia ini pasti menyentuh yang namanya matematika (Permendiknas, 2014: 325).

Kenyataannya, matematika yang telah dijadikan sebagai salah satu mata pelajaran wajib di sekolah, masih belum diminati oleh sebagian besar peserta didik. Peserta didik merasa bahwa matematika adalah pelajaran yang sulit dan membingungkan. Peserta didik kesulitan dalam memahami materi matematika. Salah satu materi yang sulit menurut hampir seluruh peserta didik adalah materi persamaan dan pertidaksamaan nilai mutlak linear satu variabel. Berdasarkan wawancara dengan guru mata pelajaran matematika kelas X SMA Negeri 1 Bangkinang Kota, diperoleh 
informasi bahwa sebagian besar peserta didik melakukan kesalahan dalam menyelesaikan soal-soal yang berkaitan dengan materi persamaan dan pertidaksamaan nilai mutlak linear satu variabel. Peserta didik salah dalam menemukan himpunan penyelesaian dari soal persamaan nilai mutlak linear satu variabel ataupun pertidaksamaan nilai mutlak linear satu variabel. Jawaban yang diberikan peserta didik menunjukkan bahwa peserta didik mengalami kesalahan dalam memahami konsep dan prinsip persamaan dan pertidaksamaan nilai mutlak linear satu variabel.

Persamaan dan Pertidaksamaan Nilai Mutlak Linear Satu Variabel adalah satu dari sekian materi yang wajib dipelajari oleh peserta didik di Sekolah Menengah Atas, tepatnya di kelas X. Adanya Persamaan dan Pertidaksamaan Nilai Mutlak Linear Satu Variabel menunjukkan bahwa materi tersebut penting untuk dipelajari oleh peserta didik agar dapat memahami materi-materi berikutnya. Masih banyaknya peserta didik yang tidak menguasai dan memahami materi Persamaan dan Pertidaksamaan Nilai Mutlak menunjukkan bahwa perlu adanya analisis yang dilakukan untuk melihat pada aspek mana saja yang perlu diperjelas dan ditekankan agar peserta didik dapat memahami materi dan tidak salah dalam memahami materi Persamaan dan Pertidaksamaan Nilai Mutlak Linear Satu Variabel tersebut.

Berdasarkan uraian tersebut, maka peneliti tertarik untuk mengetahui kesalahan yang dilakukan peserta didik, khususnya peserta didik kelas X SMA Negeri 1 Bangkinang Kota dalam menyelesaikan soal-soal pada materi Persamaan dan Pertidaksamaan Nilai Mutlak Linear Satu Variabel. Oleh karena itu, peneliti mengambil judul "Analisis Kesalahan Peserta Didik Pada Materi Persamaan dan Pertidaksamaan Nilai Mutlak Linear Satu Variabel di Kelas X SMA Negeri 1 Bangkinang Kota”.

Berdasarkan latar belakang masalah, maka dapat dirumuskan masalah sebagai berikut:

1. Aspek kesalahan apa saja yang dilakukan peserta didik kelas X SMA Negeri 1 Bangkinang kota dalam menyelesaikan soal-soal terkait materi Persamaan dan Pertidaksamaan Nilai Mutlak Linear Satu Variabel?

2. Aspek kesalahan apakah yang paling banyak dilakukan peserta didik peserta didik kelas X SMA Negeri 1 Bangkinang Kota?

3. Berapa persentase kesalahan yang dilakukan peserta didik pada masing-masing aspek?

Salah satu pembelajaran yang diperoleh peserta didik di lingkungan belajar adalah pembelajaran matematika. Terdapat banyak pengertian mengenai matematika. 
Berdasarkan beberapa pendapat ahli, Tim MKPBM menyatakan bahwa matematika dapat ditinjau dari berbagai macam perspektif, dan matematika dapat masuk dan berhubungan langsung dengan seluruh segi kehidupan manusia mulai dari yang bersifat sederhana sampai dengan yang bersifat kompleks. Matematika dapat melatih keterampilan berpikir secara logis, dan dengan matematika ilmu pengetahuan lainnya dapat berkembang dengan cepat.

Pembelajaran matematika membutuhkan proses bernalar yang tinggi dalam mengaitkan simbol-simbol dan mengaplikasikan konsep matematika yang ada dalam situasi nyata. Mempelajari matematika dituntut kesiapan peserta didik dalam menerima pelajaran, kesiapan yang dimaksud adalah kematangan intelektual dan pengalaman belajar yang telah dimiliki oleh anak, sehingga hasil belajar lebih bermakna bagi perserta didik.

Bell F.H. (1982) membagi objek matematika dalam dua kelompok yang terdiri dari objek langsung dan objek tak langsung. Objek langsung diklasifikasikan atas fakta, keterampilan, konsep, dan prinsip. Sedangkan objek tak langsung diklasifikasikan atas transfer belajar, kemampuan inkuiri, kemampuan memecahkan masalah dan apresiasi untuk struktur matematika.

Fakta dalam matematika menurut Hudojo (2005) adalah suatu ide/gagasan apabila hanya ada satu eksemplar saja ditemukan disebut fakta. Selanjutnya Bell mengemukakan bahwa fakta merupakan kesepakatan atau ketentuan dalam matematika misalnya simbol-simbol dalam matematika. Simbol " $\sqrt{ }$ " merupakan simbol untuk “akar", 1 sebagai simbol yang dihubungkan dengan perkataan "dua”, dan masih banyak lagi contoh yang lainnya. Fakta dalam matematika dapat dipelajari melalui belajar hafalan, latihan, dan permainan. Peserta didik dikatakan telah memahami fakta jika dapat menuliskan fakta dengan benar dan dapat menggunakan dengan tepat dalam situasi yang berbeda.

Bell (1982) mengemukakan bahwa keterampilan dalam matematika merupakan operasi dan prosedur dimana peserta didik diharapkan dapat menyelesaikan persoalan dengan cepat dan tepat. Berbagai keterampilan berwujud urutan prosedur tertentu yang disebut dengan algoritma. Sedangkan operasi itu sendiri adalah suatu aturan untuk mendapatkan elemen tunggal dari satu atau lebih elemen yang diketahui, misalnya 
menjumlahkan $\sin \alpha$ dengan $\sin \alpha$, mengalikan $\cos \alpha$ dengan $\cos \alpha$, atau mengalikan $\sin \alpha$ dengan suatu bilangan real merupakan contoh dari keterampilan.

Hal ini sesuai dengan apa yang dikemukakan oleh Hudojo bahwa keterampilan dimaksudkan agar peserta didik mampu menjalankan prosedur dan operasi dalam matematika secara tepat dan benar. Keterampilan dalam matematika dapat dipelajari antara lain melalui demonstrasi dan berbagai bentuk latihan seperti kerja kelompok dan permainan. Seseorang dikatakan telah menguasai suatu keterampilan apabila telah dapat mendemonstrasikan dengan benar keterampilan tersebut dengan menyelesaikan berbagai bentuk masalah yang memerlukan keterampilan itu, atau dapat menerapkannya dalam berbagai macam situasi.

Konsep dalam matematika menurut Hudojo adalah "suatu ide/gagasan yang dibentuk dengan memandang sifat-sifat yang sama dari sekumpulan eksemplar yang cocok. Dengan mengambil adanya sekumpulan eksemplar sebagai kriteria, kita mengidentifikasi konsep. Apabila kita dapat menemukan lebih dari satu eksemplar dari suatu ide/gagasan, kita namakan suatu konsep". Contoh " $x<y$ " merupakan konsep sebab kita dapat menyebutkan fakta misalkan $2<3$. Sedangkan menurut Bell17 konsep adalah suatu ide abstrak yang memungkinkan seseorang untuk mengklasifikasikan objek-objek atau kejadian-kejadian dan menentukan apakah objek-objek atau kejadian-kejadian itu merupakan contoh atau bukan contoh dari ide tersebut. Soedjadi 18 juga mengatakan bahwa konsep adalah ide abstrak yang dapat digunakan untuk menggolongkan atau mengklasifikasikan sekumpulan objek. Apakah objek tertentu merupakan contoh konsep ataukah bukan. Sinus, cosinus, tangen, cotangen, secan, dan cosecan, semua ini merupakan contoh dari konsep. Konsep dalam Matematika dapat dipelajari melalui definisi atau observasi langsung.

Persamaan dan pertidaksamaan nilai mutlak linear satu variabel adalah salah satu materi yang dipelajari di kelas X SMA sesuai dengan kurikulum 2013. Konsep persamaan dan pertidaksamaan nilai mutlak linear satu variabel ditemukan dan diterapkan dalam penyelesaian masalah matematika termasuk masalah yang ada di kehidupan nyata. Penguasaan terhadap konsep dan sifat-sifat persamaan dan pertidaksamaan linear nilai mutlak satu variabel yang merupakan bagian dari persamaan dan pertidaksamaan linear adalah syarat perlu untuk mempelajari materi sistem persamaan dan pertidaksamaan linear dua variabel dan tiga variabel. 


\section{METODE PENELITIAN}

Metode pada penelitian ini adalah metode deskriptif kualitatif dan desriptif kuantitatif. Deskriptif kualitatif yaitu menggambarkan kesalaha-kesalahan yang dilakukan peserta didik dengan menggunakan kata-kata. Sedangkan deskriptif kuantitatif yaitu menggambarkan besar kesalahan-kesalahan yang dilakukan peserta didik dengan menggunakan angka. Suharsimi Arikunto (2006: 12) mengemukakan bahwa penelitian kuantitatif adalah pendekatan penelitian yang banyak dituntut menggunakan angka, mulai dari pengumpulan data, penafsiran terhadap data tersebut, serta menampilkan hasil. Menurut Sumanto (1995: 77) penelitian deskriptif berusaha mendeskripsi dan menginterpretasi apa yang ada (bisa mengenai kondisi atau hubungan yang ada, pendapat yang sedang tumbuh, proses yang sedang berlangsung, akibat yang terjadi atau kecederungan yang tengah berkembang).

Populasi dalam penelitian ini adalah seluruh peserta didik kelas X SMA Negeri 1 Bangkinang Kota, sedangkan sampel yang bersifat representative dari populasi diambil dari peserta didik di kelas XI IPA 1 sebanyak 30 orang dan X MIPA 4 sebanyak 32 orang. Objek dalam penelitian yaitu kesalahan peserta didik dalam menyelesaikan soal matematika yang berkaitan dengan materi Persamaan Linear Dua Variabel

Penelitian dilaksanakan di kelas X MIPA 4 SMA Negeri 1 Bangkinang Kota tahun ajaran 2017/2018 pada bulan April 2017. Teknik pengumpulan data yang digunakan dalam penelitian ini adalah metode tes. Suharsimi Arikunto (2006: 150) menyatakan bahwa tes adalah serentetan pertanyaan atau latihan serta alat lain yang digunakan untuk mengukur keterampilan, pengetahuan intelegensi. Tes tersebut dilakukan di kelas secara bersama-sama tanpa membuka buku catatan atau buku paket peserta didik dengan alokasi waktu 90 menit.

Instrumen penelitian yang digunakan oleh peneliti sebagai alat pengumpulan data adalah tes. Tes ini terdiri dari beberapa soal yang disesuaikan dengan kebutuhan penelitian. Instrument tes yang digunakan dalam penelitian ini bersifat diagnostik artinya hanya ingin mengetahui letak kesalahan peserta didik dan tidak digunakan dalam menilai prestasi peserta didik dalam mengerjakan soal terkait materi persamaan dan pertidaksamaan nilai mutlak linear satu variabel. 
Teknik analisis data yang digunakan dalam penelitian ini adalah analisis deskriptif, yaitu menganalisis data dengan cara mendeskripsikan atau menggambarkan data yang telah terkumpul. Data yang diperoleh dalam penelitian ini adalah data hasil tes diagnostic. Setelah data terkumpul dilakukan reduksi data, yang bertujuan untuk memfokuskan data pada hal-hal yang akan diteliti. Mereduksi data merupakan kegiatan penyederhanaan dan pengabstraksian seluruh data dari hasil tes. Pada tiap aspek kesalaahan dapat dihitung menggunakan rumus

Adapun proses analisis terhadap lembar jawaban peserta didik adalah sebagai berikut:

1. Memeriksa jawaban soal pada lembar jawaban peserta didik

2. Menghitung persentase peserta didik yang salah dalam mengerjakan soal pada tiap aspek kesalahan

3. Mengurutkan persentase aspek kesalahan peserta didik

4. Mendeskripsikan data yang sudah dikelompokkan berdasarkan aspek kesalahan

\section{HASIL DAN PEMBAHASAN}

Berdasarkan hasil tes diagnostik pada materi persamaan dan pertidaksamaan nilai mutlak linear satu variabel diperoleh bahwa masih terdapat peserta didik yang melakukan kesalahan dalam menyelesaikan soal terkait materi tersebut. Kesalahan yang dilakukan peserta didik terdiri dari kesalahan konsep, dan kesalahan prinsip. Materi persamaan dan pertidaksamaan nilai mutlak linear satu variabel membutuhkan kemampuan memahami konsep, prinsip, dan skill. Aspek konsep artinya memahami definisi dari persamaan dan pertidaksamaan nilai mutlak linear satu variabel. Aspek yang kedua yaitu prinsip merupakan pemahaman terhadap teorema dan aturan-aturan yang telah ditetapkan dalam menemukan penyelesaian dari persamaan dan pertidaksamaan nilai mutlak linear satu variabel. Sedangkan aspek prinsip berkaitan dengan kemampuan menyusun algoritma dan melakukan operasi perhitungan sehingga menghasilkan jawaban yang benar dan tepat. Setiap kemampuan mempengaruhi langkah penyelesaian soal matematika. Jika salah satu kemampuan tersebut tidak dimiliki oleh peserta didik maka dapat mengakibatkan proses dan hasil yang salah dalam menyelesaikan soal persamaan dan pertidaksamaan nilai mutlak linear satu variabel. Hasil analisis terhadap hasil tes peserta didik dalam menyelesaikan soal persamaan dan pertidaksamaan nilai mutlak linear satu variabel disajikan pada Tabel 1. 
Tabel 1. Jenis Kesalahan Pada Materi Persamaan dan Pertidaksamaan Nilai Mutlak Linear Satu Variabel

\begin{tabular}{|c|c|c|c|}
\hline \multirow{2}{*}{ No Soal } & \multicolumn{3}{|c|}{ Jenis Kesalahan } \\
\cline { 2 - 4 } & $\begin{array}{c}\text { Kesalahan } \\
\text { Keterampilan }(\%)\end{array}$ & $\begin{array}{c}\text { Kesalahan Konsep } \\
(\%)\end{array}$ & $\begin{array}{c}\text { Kesalahan Prinsip } \\
(\%)\end{array}$ \\
\hline $1 \mathrm{a}$ & $9 \%$ & $73 \%$ & $73 \%$ \\
\hline $1 \mathrm{~b}$ & 0 & $82 \%$ & $82 \%$ \\
\hline 2 & 0 & $64 \%$ & $73 \%$ \\
\hline 3 & 0 & $73 \%$ & $73 \%$ \\
\hline 4 & 0 & $55 \%$ & $64 \%$ \\
\hline $5 \mathrm{a}$ & 0 & $82 \%$ & $73 \%$ \\
\hline $5 \mathrm{~b}$ & 0 & $55 \%$ & $55 \%$ \\
\hline
\end{tabular}

Berdasarkan Tabel 1. terlihat bahwa persentase kesalahan yang dilakukan peserta didik dalam menyelesaikan soal-soal persamaan dan pertidaksamaan nilai mutlak linear satu variabel adalah kesalahan prinsip 71\% dan kesalahan konsep 69\%. Berdasarkan hal tersebut maka dapat disimpulkan bahwa kesalahan yang paling banyak dilakukan peserta didik dalam menyelesaikan persamaan dan pertidaksamaan nilai mutlak linear satu variabel adalah kesalahan prinsip diikuti kesalahan konsep.

\section{UCAPAN TERIMA KASIH}

Terimakasih peneliti ucapkan kepada Bapak Dekan Fakultas Ilmu Pendidikan, Ketua Prodi Pendidikan Matematika yang telah memberikan izin kepada peneliti untuk melakukan penelitian. Terimakasih peneliti juga sampaikan kepada Kepala Sekolah SMA Negeri 1 Bangkinang Kota, serta guru mata pelajaran matematika yang telah memberikan kesempatan kepada peneliti untuk melakukan penelitian di SMA Negeri 1 Bangkinang Kota.

\section{DAFTAR PUSTAKA}

Arikunto, S. (2010). Prosedur Penelitian, Rineka Cipta. Jakarta.

Abidin, Zainal. Analisis Kesalahan Mahasiswa Prodi Pendidikan Matematika Fakultas Tarbiyah IAIN Ar-Raniry dalam Mata Kuliah Trigonometri dan Kalkulus 1. Diterbitkan pada Jurnal Ilmiah DIDAKTIKA Agustus 2012.

Bell, F.H. (1982). Teaching and Learning Mathematics (In Secondary School), Wm. C. Brown Company Publisher, Lowa.

Hudojo, Herman. (2005). Pengembangan Kurikulum dan Pembelajaran Matematika. Malang: Penerbit Universitas Negeri Malang. 
Sumanto. (1995). Metodologi Penelitian Sosial dan Pendidikan. Yogyakarta: Andi Offset. 